\title{
PERILAKU MAKANAN YANG TIDAK SEHAT LEBIH BERESIKO LEBIH TINGGI DALAM KEJADIAN PREEKLAMSIA PADA KESEHATAN IBU HAMIL
}

PUTRI WIDIYASTUTI.S ${ }^{1}$

\author{
${ }^{1}$ Universitas Islam Negehri Alauddin Makassar \\ Email : widiyastutisp@gmail.com
}

\section{PENDAHULUAN}

Preeklamsia (PE) merupakan penyumbang mortalitas dan morbiditas ibu dan bayi. Preeklamsia adalah penyebab terbesar kedua kematian ibu, mempengaruhi 3\% sampai 8\% wanita hamil di seluruh dunia. Hampir 18\% dari kematian ibu karena preeklamsia sebagian besar terjadi di negara berkembang ${ }^{(1)}$. Preeklamsia merupakan salah satu masalah kesehatan yang sering terjadi pada kehamilan. Preeklamsia didefinisikan sebagai peningkatan tekanan darah yang disertai dengan tanda gejala hipertensi dan peningkatan protein urin yang biasanya terjadi pada kehamilan TM III. Jika tidak segera mendapatkan penanganan awal, preeklamsia bisa berlanjut menjadi eklamsia $^{(1,2)}$. Di indonesia, hipertensi merupakan penyebab pertama tingginya kematian ibu. Tahun 2015 AKI menjadi 305/100.000 KH. Pada tahun 2024 ditargetkan AKI turun menjadi 232/100.000 KH. Persentase penyebab kematian ibu diketahui sebesar 33,07\% hipertensi, 27,03\% perdarahan, 15,7\% komplikasi non obstetric, 12,04\% komplikasi obstetric, 6,06\% infeksi dan 4,81\% lain-lain (3,4). Prevalensi kejadian preeklamsia di Jawa timur tahun 2018 sebesar 31\% atau sebanyak 163 orang. Hal ini cenderung meningkat dibandingkan dengan kejadian preeklamsia pada tahun 2017 sebesar 28,92\% atau sebanyak 153 orang. Sedangkan AKI di Jawa Timur pada tahun 2018 mengalami penurunan dari tahun sebelumnya, dari 529 orang menjadi 522 orang ${ }^{(5,6)}$. Preeklamsia merupakan penyumbang kedua kematian ibu. Persentase penyebab kematian ibu di Jawa Timur tahun 2018 diketahui penyebab lain-lain yaitu 32\% atau 170 orang, Pre Eklamsi / Eklamsi yaitu sebesar 31\% atau sebanyak 163 orang dan perdarahan yaitu $23 \%$ atau sebanyak 119 orang, jantung 10\% atau 51 orang. Sedangkan penyebab paling kecil adalah infeksi sebesar 4\% atau sebanyak 19 orang ${ }^{(6)}$. Berdasarkan studi pendahuluan dari data LB3KIA, prevalensi kejadian preeklamsia pada ibu hamil di Kabupaten Magetan tahun 2017 sebanyak 189 orang. Sedangkan pada tahun 2018 
sebanyak 270 orang. Hal ini menunjukkan bahwa terjadi peningkatan angka kejadian preeklamsia dari tahun 2017 ke tahun 2018 yaitu sebanyak 81 orang. Kejadian tertinggi di wilayah Puskesmas Panekan sebanyak 27 orang. Preeklamsia menjadi penyebab kematian kedua setelah perdarahan yaitu sebanyak 2 orang meninggal karena preeklamsia atau sebesar 15,38\% per $100.000 \mathrm{KH}^{(3,4)}$

Faktor penyebab Preeklamsia adalah status kesehatan ibu, status reproduksi, status gizi, akses kepelayanan kesehatan dan perilaku kesehatan ${ }^{(7)}$. Perilaku kesehatan merupakan suatu respon terhadap rangsangan. Perilaku kesehatan terdiri dari 3 aspek salah satunya perilaku gizi/ perilaku makan. Dampak yang bisa dialami ibu hamil dengan preeklamsia ada 2 yaitu dampak bagi janin dan bagi ibu sendiri. Bagi janin dapat menyebabkan gangguan pertumbuhan (IUGR), kematian janin dalam kandungan (IUFD), BBLR. Sedangkan dampak bagi ibu adalah ibu menjadi tidak sadar (koma) sampai meninggal ${ }^{(2,8)}$. Besarnya pengaruh preeklamsia terhadap tingginya kematian ibu dan banyaknya dampak daripreeklamsia terhadap kesehatan ibu, maka perlu dilakukan upaya untuk mencegah dan menangani kasus-kasus preeklamsia. Strategi pemerintah dalam menurunkan Angka Kematian Ibu di Indonesia ${ }^{(7,8)}$ adalah melalui strategi intervensi yang terdiri dari empat hal utama yaitu peningkatan akses pelayanan kesehatan, peningkatan kualitas pelayanan kesehatan, pemberdayaan masyarakat dan penguatan tata kelola. Strategi tersebut meliputi pelayanan ANC berkualitas sesuai standart $10 \mathrm{~T}$, ibu hamil dan bersalin di fasilitas kesehatan, ANC dan PNC yang berkualitas, deteksi dini, sistem rujukan yang terintegrasi serta RS sayang ibu dan bayi ${ }^{(9,10)}$

\section{Kejadian Preeklamsia Ibu Berdasarkan Usia}

Hasil penelitian menunjukkan bahwa ibu berdasarkan usia pada ibu preeklamsia dan tidak preeklamsia menunjukkan persamaan yaitu mayoritas responden berusia 20-35 tahun. Namun, hampir separuh ibu preeklamsia terjadi pada usia $>35$ tahun. Disebutkan insiden tertinggi kasus preeklamsia terjadi pada usia remaja atau awal usia 20 tahun, tetapi prevalensinya meningkat pada wanita diatas 35 tahun $^{(7)}$. Keterangan lain dijelaskan bahwa usia terlalu muda atau terlalu tua merupakan faktor terjadinya preeklamsia. Usia kurang dari 20 tahun sangat beresiko karna belum matangnya alat reproduksi untuk hamil, dan $>35$ tahun fungsi organ reproduksi juga mulai mengalami penurunan sehingga tidak dapat bekerja secara maksimal. Ibu yang berumur kurang 
dari 20 tahun dan lebih 35 tahun berpotensi 3x lipat terkena preeklamsia dibandingkan dengan ibu hamil yang berusia 20-35 tahun. Namun kenyataannya, pada hasil penelitian ini usia ibu yang tidak beresiko juga memberikan banyak sumbangsih terhadap kejadian preeklamsia ${ }^{(12,13) .}$ Hasil penelitian ini juga sejalan dengan penelitian yang dilakukan di ruang Kebidanan RSUP Dr.M. Djamil Padang Tahun 2016 menunjukkan bahwa umur ibu hamil sebagian besar tidak beresiko pada preeklampsia dan sebagian kecil umur ibu hamil yang beresiko terhadap pre-eklampsia ${ }^{(8)}$. Penelitian,lain menyebutkan prevalensi kejadian preeklamsia pada ibu yang berusia 20-35 tahun masih tinggi, untuk itu disarankan ibu hamil melakukan pemeriksaan ANC yang rutin agar deteksi dini preeklamsia dapat dilakukan. Sehingga, kematian dan kesakitan ibu karena preeklamsia dapat dicegah ${ }^{(14)}$.

\section{Kejadian preeklamsia Ibu Berdasarkan Paritas}

Hasil penelitian berdasarkan paritas ibu yang mengalami preeklamsia dan tidak preeklamsia hampir separuhnya terjadi pada Primipara dan sebagian besar terjadi pada. Hal ini menunjukkan bahwa kejadian preeklamsia terbanyak terjadi pada ibu multipara.Hasil penelitian ini sejalan dengan penelitian yang dilakukan oleh Pandiangan J.M dan Kusnanto H (2017) yaitu sebanyak 25,23\% preeklamsia terjadi pada primipara, sedangkan pada multipara sebanyak $35,51 \%$. Penelitian menunjukkan bahwa paritas ibu yang mengalami preeklamsia lebih banyak terjadi pada multipara dari pada primipara.

Prevalensi kejadian peeklamsia dari hasil penelitian sebelumnya didapatkan hasil mayoritas ibu hamil yang megalami preklamsia adalah multipara Hal ini berbeda dengan dengan penelitian lain yang menyatakan bahwa primipara merupakan faktor resiko terjadinya preeklamsia dikarenakan pada penelitian ini didapatkan ibu yang mengalami preeklamsia kebanyakan terjadi pada multipara, ${ }^{(7)}$.Berdasarkan hasil penelitian, peneliti menyimpulkan bahwa preeklamsia dapat terjadi pada ibu Primi para maupun Multipara. ibu Primipara maupun Multipara samasama mempunyai resiko untuk mengalami preeklamsia. Oleh karena itu, disarankan Bidan dapat memberikan pelayanan ANC yang berkwalitas dan bidan dapat melakukan screening preeklamsia, sehingga diagnose preeklamsia dapat ditemukan sedini mungkin. 


\section{Kejadian Preeklamsia Ibu Berdasarkan Pendidikan}

Hasil penelitian mengenai karakteristik ibu yang mengalami preeklamsia dan tidak preeklamsia berdasarkan pendidikan didapatkan hasil pendidikan ibu banyak adalah tingkat pendidikan SMA.Pendidikan seseorang berhubungan dengan kesempatan menyerap informasi mengenai pencegahan dan faktor-faktor risiko preeklamsia. Tetapi pendidikan ini akan dipengaruhi oleh seberapa besar motivasi, atau dukungan lingkungan seseorang untuk menerapkan pencegahan dan faktor risiko preeklamsia ${ }^{(8,18)}$. Hasil penelitian sebelumnya juga didapatkan hasil bahwa sebagian ibu yang mengalami preeklamsia berpendidikan SMA. Seperti pada penelitian yang dilakukan oleh Pandiangan J.M dan Kusnanto H (2017) da penelitian yang dilakukan oleh Taslim R.W.R, dkk (2016) juga didapatkan hasil mayoritas responden berpendidikan SMA. Hasil penelitian ini bertolak belakang dengan hasil penelitian yang menyatakan bahwa ibu yang status pendidikannya rendah (tidak sekolah, SD, SMP) beresiko mengalami preeklamsia ${ }^{(16)}$.

\section{Karakteristik Ibu Berdasarkan Pekerjaan}

Hasil penelitian didapatkan hasil hampir separuhnya ibu yang mengalami preeklamsia tidak bekerja (IRT). Sedangkan pada kelompok ibu yang tidak mengalami preeklamsia didapatkan hasil terbanyak adalah ibu bekerja sebagai wiraswasta. Hasil penelitian ini dikuatkan dengan hasil penelitian lain yang menyatakan bahwa pekerjaan mempengaruhi tingkat stress yang memicu timbulnya hipertensi dan dapat meningkatkan resiko terjadinya preeklamsia, ${ }^{(18,19)}$. Hal ini sebabkan karena ibu yang tidak bekerja akan merasakan stres yang mungkin dirasakan setiap hari karena kurangnya kegiatan dilua rumah yang membuat ibu hamil sering bosan, oleh karena itu bidan perlu memberikan penyuluhan kepada ibu hamil untuk sesering mungkin melakukan kegiatan diluar rumah misalnya berjalan-jalan setiap pagi hari, mengikuti kelas ibu hamil, dan rekreasi setiap sudah mulai merasa bosan didalam rumah

\section{Pengaruh Perilaku Makan Selama Hamil Terhadap Kejadian Preeklamsia}

Hasil penelitian ini ibu hamil yang mempunyai perilaku makan tidak sehat mempunyai resiko 35x lebih besar akan mengalami preeklamsia daripada ibu hamil yang mempunyai perilaku 
makan sehat. Penelitian lain menyebutkan bahwa perilaku asupan zat gizi/ pada ibu hamil, kebiasaan mengonsumsi makanan tinggi lemak dan tinggi garam, ketidak seimbangan menu makanan akan membentuk stress oksidatif dapat menyebabkan terjadinya pre eklamsia selama kehamilan, ${ }^{(9,15,16,17)}$. Ibu hamil memerlukan makan yang mempunyai kelengkapan gizi hal ini penting terutama pada umur kehamilan 20 minggu, pada saat ini sebaiknya ibu hamil tidak mengkonsumsi nutrisi yang tinggi natrium dan rendah protein karena dapat menyebabkan gangguan kehamilan seperti pre-eklamsi. Dampak dari gangguan pola nurisi selama kehamilan bisa berakibat dengan semakin meningkatnya angka kejadian pre-eklamsi yang ditandai dengan gejala tekanan darah tinggi, kelebihan kadar protein pada urin, edema kaki, penglihatan kabur, sesak nafas dan menurunnya kesadaran dan kejang. Berdasarkan hasil penelitian diatas peneliti berpendapat bahwa perilaku makan selama hamil berpengaruh pada status kesehatan ibu yang akan meningkatkan angka kesakitan ibu hamil, salah satunya yaitu karena preeklamsia ${ }^{(17,18)}$

\section{Perbedaan Perilaku Makan Kelompok Preeklamsia dan Tidak Preeklamsia Berdasarkan Hasil Kuesioner}

\begin{tabular}{|c|c|c|}
\hline Kuesioner & Preeklamsia & Tidak Preeklamsia \\
\hline 1. Makanan atau minuman manis & 1x perhari & 3-6x perminggu \\
\hline 2. Makanan Asin & 1x perhari & 3-6x perminggu \\
\hline $\begin{array}{l}\text { 3.Makanan berlemak / berkolesterol/ } \\
\text { gorengan }\end{array}$ & 1x perhari & 3-6x perminggu \\
\hline 4. Makanan yang dibakar & $<3 x$ perbulan & Tidak pernah \\
\hline $\begin{array}{l}\text { 5. Makanan daging / ayam / ikan olahan } \\
\text { dengan pengawet }\end{array}$ & $3-6 x$ perminggu & Tidak pernah \\
\hline 6. Bumbu penyedap & $1 \mathrm{x}$ perhari & 1x perhari \\
\hline 7. Kopi & $>1 \mathrm{x}$ perhari & Tidak pernah \\
\hline 8. Minuman berkafein buatan bukan kopi & $3-6 x$ perminggu & Tidak pernah \\
\hline 9. Mie instan / mie basah & $3-6 x$ perminggu & $<3 \mathrm{x}$ perbulan \\
\hline 10. Roti/biskuit & 1x perhari & $3-6 x$ perminggu \\
\hline
\end{tabular}




\section{DAFTAR PUSTAKA}

1. (DOI: Http://Dx.Doi.Org/10.33846/2trik10201 Dampak Perilaku Makan Terhadap Kejadian Pre Eklamsia Pada Ibu Hamil Yetty Wilda, 2020)

2. Adha, A. S., Bahtiar, N. W., Ibrahim, I. A., Syarfaini, S., \& Nildawati, N. (2021). Analisis Hubungan Pola Asuh Ibu Dengan Kejadian Stunting Pada Balita Di Kabupaten Jeneponto. Al GIZZAI: PUBLIC HEALTH NUTRITION JOURNAL, 1(2), 71-82. http://journal.uinalauddin.ac.id/index.php/alghidza/article/view/21825

3. All, E. at. (2013). Hubungan Pola Pemberian Mp-Asi Dengan Status Gizi Anak Usia 6-36 Bulan. 1(2), 103-110.

4. Darwis, A. M., Nirwana, A., Burhamzah, R., Patimang, C., Masyarakat, F. K., \& Hasanuddin, U. (2021). Pengetahuan Masyarakat Tentang Penggunaan Tanaman Obat Keluarga Sebagai Peningkatan Imun Selama Pandemi Penelitian ini menggunakan PreExperimental Design yaitu studi kasus one- shot. Instrument penelitian berupa Buku Pedoman Tanaman Obat Keluarga dalam . 1(2), 83-88.

5. Ibrahim, I. A., Syahrir, S., \& Anggriati, T. (2021). Faktor-Faktor Yang Berhubungan Dengan Hyperemesis Gravidarum Pada Ibu Hamil Di RSUD Syekh Yusuf Tahun 2019. Al Gizzai: Public Health Nutrition Journal, 1(2), 59-70.

6. Jayadi, Y. I., Ansyar, D. I., Alam, S., \& Sayyidinna, D. A. (2021). Evaluasi Program Pemberian Makanan Tambahan Anak Balita Pada Masa Pandemi Covid 19 di Puskesmas Kabupaten Gowa Kese Terdapat 45 \% kematian pada anak di bawah usia 5 tahun terkait dengan Tambahan untuk Anak Balita, Anak Usia Sekolah Dasar , dan Ibu Hamil. 1(2), 89-102.

7. Nurhikmah, Sudarman, S., \& Aswadi. (2021). Hubungan Pola Makan Dan Perilaku Dengan Kejadian Stroke di RSUD Lanto Daeng Pasewang Kabupaten Jeneponto. Al Gizzai: Public Health Nutrition Journal, 1(2), 111-123. 